\title{
Heavy metals concentrations and burden in the bivalves (Anadara (Senilia) senilis, Crassostrea tulipa and Perna perna) from lagoons in Ghana: Model to describe mechanism of accumulation/excretion
}

\author{
Fred A. Otchere \\ Azimuth Consulting Group, 218 - 2902 West Broadway, Vancouver, British Columbia.V6K 2G8 Canada, E-mail: \\ atotchere@yahoo.co.uk; phone: 1.604.608.4283.
}

Accepted 29 July 2003

\begin{abstract}
Seasonal sampling of the bivalves: Anadara (Senilia) senilis $(n=260)$, Crassostrea tulipa $(n=220)$, from two 'open' lagoons (Benya and Ningo) and a 'closed' lagoon (Sakumo), and Perna perna $(n=170)$, from rocky shores adjacent to Benya and Sakumo, were analyzed for their total $\mathrm{Cu}, \mathrm{Zn}, \mathrm{Fe}, \mathrm{Mn}, \mathrm{Cd}$ and $\mathrm{Hg}$ concentrations and total body burden (that is concentration multiply by total flesh weight). Median concentrations for cockles were: $5,38,710,10,0.22$ and $0.20 \mu \mathrm{g} / \mathrm{g} \mathrm{dw}$ respectively. Cd and $\mathrm{Hg}$ levels in dry season samples were higher than those in wet season. While $\mathrm{Zn}$ and Fe dry season levels were lower than wet season with no variation in $\mathrm{Cu}$ and $\mathrm{Mn}$. Median total body burden in cockles were: 3.3, $30.5,370,5.2,0.28$ and $0.13 \mu \mathrm{g}$ respectively. Geographical variations observed were mostly due to size distribution rather than the ecological differences between stations. Log-transformed regression relationships between body burden and size were used to compare the species. Relationship between condition index, body burden and concentration were used to develop a model to describe mechanism of accumulation/excretion.
\end{abstract}

Key words: Heavy metals, bivalves, marine, lagoons, seasonal variation, accumulation, Ghana.

\section{INTRODUCTION}

Monitoring programs and research for metals in the environmental samples have become widely established because of concerns over accumulation and toxic effects, particularly in aquatic organisms and to humans consuming these organisms. The criteria by which organisms are accepted as biological indicator for the assessment of contamination were proposed more than twenty five years ago and remain unchanged (Phillips, 1976; Fowler and Oregioni, 1976). Bivalves are widely used as bioindicators of heavy metals pollution in coastal areas because they are known to concentrate these elements, providing a time integrated indication of environmental contamination. In comparison to fish and crustacea, bivalves have a very low level of activity of enzyme systems capable of metabolizing persistent organic pollutants (POPs), such as aromatic hydrocarbons and polychlorinated biphenyls. Therefore contaminants concentrations in the tissues of bivalves more accurately reflect the magnitude of environmental contamination (Phillips, 1977, 1980, 1990).

Factors known to influence metal concentrations and accumulation in these organisms include metal bioavailability, season of sampling, hydrodynamics of the environment, size, sex, changes in tissue composition and reproductive cycle (Boyden and Phillips, 1981). Seasonal variations have been related to a great extent 
to seasonal changes in flesh weight during the development of gonadic tissues (Joiris et al., 1998, 2000). Element concentrations in molluscs at the same location differ between different species and individuals due to species-specific ability/capacity to regulate or accumulate trace metals (Reinfelder et al., 1997; Otchere et al., 2003). Different animals in the same community at the same trophic level could accumulate pollutants differently due to differences in habitat/niche's physical and chemical properties.

This paper presents data on the total concentration and body burden of six metals, the effect of season on these bivalves and a model developed to explain excretion and accumulation of these metals in the bivalves.

\section{MATERIALS AND METHODS}

Three species of bivalves were collected from the lagoons of Ghana (which lies between latitude $4^{\circ}$ and $115^{\circ} \mathrm{N}$ ) with approximately $590 \mathrm{~km}$ long coastline, stretches from $3^{\circ} \mathrm{W}$ to $1^{\circ}$ $10^{\prime} \mathrm{E}$ and lies between $4^{\circ} 5^{\prime}$ and $6^{\circ} 6^{\prime} \mathrm{N}$. About 50 lagoons occur on the coast. The lagoons are of two main types: 'open' and 'closed' lagoons. The open lagoons are in contact with the sea throughout the year and therefore partly under tidal influence. Temperature and salinity ranges are 24 to $32^{\circ} \mathrm{C}$ and 10 to $40 \mathrm{psu}$, respectively. The closed lagoons are cut off from the adjacent sea by a sand bar (about $40 \mathrm{~m}$ wide) for the greater part of the year. Temperature and salinity ranges are: 27 to $34^{\circ} \mathrm{C}$ and 27 to 70 psu, respectively. Hyperhaline condition results from evaporation during the dry season (Yankson, 1982).

Samples of Anadara (Senilia) senilis (cockles; $n=260$ ), and Crassostrea tulipa (oysters; $n=220$ ) from three lagoons and Perna perna (mussels; $n=170$ ) from two rocky shores adjacent to these lagoons, were collected in October 1996 and February 1997 (wet and dry seasons, respectively). The analytical procedure used to measure the metals $\mathrm{Cd}, \mathrm{Cu}, \mathrm{Fe}, \mathrm{Mn}$ and $\mathrm{Zn}$; in the bivalves was based on UNEP/FAO/IAEA (1982) with modification as follows: sub-sample (dried) tissue $(0.2 \mathrm{~g})$ was heated with $10 \mathrm{ml}$ of concentrated nitric acid $\left(70\right.$ to $\left.90^{\circ} \mathrm{C}\right)$ till all tissue had been digested. The temperature was then gradually increased to $135^{\circ} \mathrm{C}$ and drops of $\mathrm{H}_{2} \mathrm{O}_{2}$ added for further oxidation. After cooling, solutions were diluted to $50 \mathrm{ml}$ with double distilled water and filtered with 1.6 $\mu \mathrm{m}$ fiberglass filter paper (GF/A).

Samples were then stored at room temperature in $50 \mathrm{ml}$ volumetric flask until they were analyzed. Analyses were carried out with flame Atomic Absorption Spectrophotometer (AAS) (Perkin Elmer 3110 system 2) with electrode discharge lamps (EDL) and hollow cathode lamp (HCL). Wavelengths and detection limits are shown in Table 2. Air-acetylene oxidizing flame was used, with $1 \mathrm{ml}$ autosampler, each sample was measured three times and the concentration of the sample given as the mean of the three measurements. The AAS was calibrated for each metal with the following standard solutions $5,10,15,20$ and 25 ppm (from 1000 ppm stock solution) before each metal determination. All reagents used were of analytical grade (Analar). Method for the determination of $\mathrm{Hg}$ has been described in Joiris et al. (1998). Samples prepared for metal analysis included procedural blanks, replicate analyses, standard solutions and certified reference material (CRM) of dogfish muscle (DORM-2, National Research Council of Canada, Marine Analytical Chemistry Standards Program). The certified values for selected heavy metals are shown in Table 1 (no corrections carried out).

The data were expressed as total concentration and body burden. Median values are presented and differences were tested using the Mann-Whitney U-test of significance due to the nonnormal distribution of the data. The species were compared using log transformed regression analysis. Relationship between condition index, body burden and concentration were used to develop a model to describe mechanism of accumulation/excretion.

Table 1. Comparison between certified metal concentrations in CRM DORM-2 and values obtained from this study ( $\mu \mathrm{g} / \mathrm{g} \mathrm{dw}$ ).

\begin{tabular}{|l|l|l|c|}
\hline Element & Certified value & Value found & $\%$ of target value \\
\hline Cadmium & $0.043 \pm 0.008$ & $0.036 \pm 0.006$ & 84 \\
Copper & $2.34 \pm 0.16$ & $2.04 \pm 0.16$ & 87 \\
Iron & $142 \pm 10$ & $133 \pm 14$ & 94 \\
Manganese & $3.66 \pm 0.34$ & $3.2 \pm 0.12$ & 87 \\
Mercury & $0.789 \pm 0.074$ & $0.765 \pm 0.029$ & 96 \\
Zinc & $25.6 \pm 2.3$ & $22.7 \pm 2$ & 89 \\
\hline
\end{tabular}

Table 2. Wavelengths $(\mathrm{nm})$ used to measure the metals, sensitivity of the AAS (mg/l) and detection limits (ng/g).

\begin{tabular}{|l|c|c|c|}
\hline Element & Wavelength & Sensitivity & Detection limit \\
\hline Cadmium & 228.8 & 0.0005 & 2.13 \\
Copper & 324.7 & 0.001 & 3.9 \\
Iron & 248.3 & 0.003 & 183 \\
Manganese & 279.5 & 0.001 & 30 \\
Mercury & 253.7 & 0.001 & 40 \\
Zinc & 213.9 & 0.0008 & 441 \\
\hline
\end{tabular}



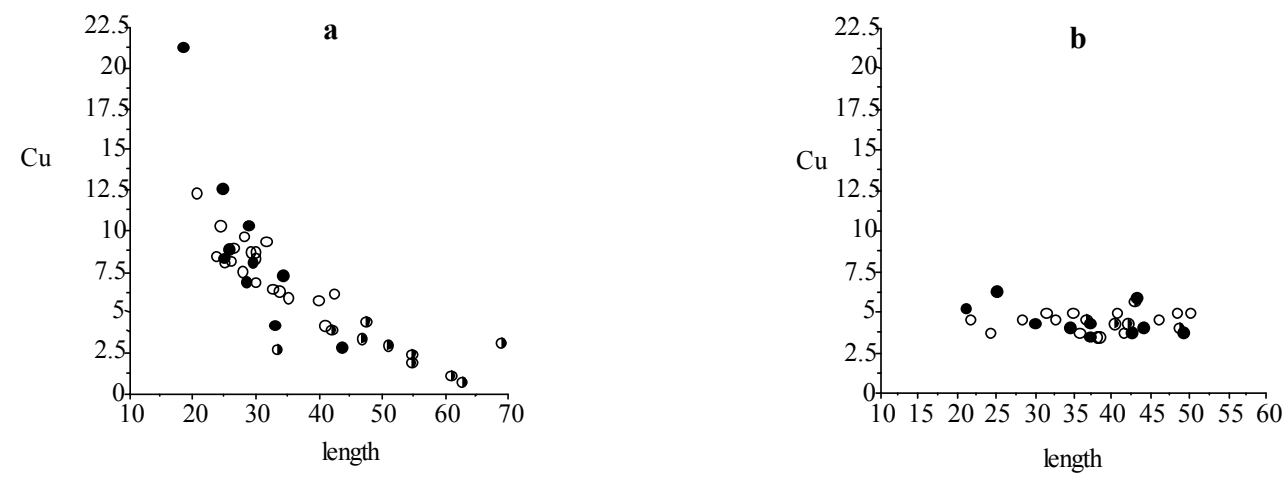

Figure 1. Relationship between Cu concentrations ( $\mu \mathrm{g} / \mathrm{g} \mathrm{dw})$ in cockles and size $(\mathrm{mm})$ : dry (a) and wet (b) seasons; Benya (circles), Ningo (half shaded) and Sakumo (dots) lagoons.
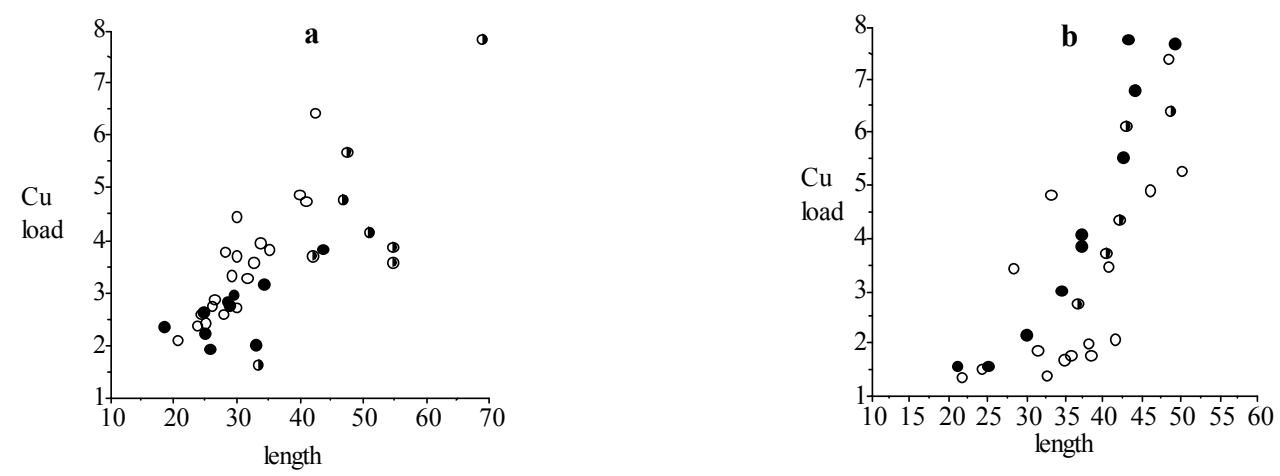

Figure 2. Relationship between $\mathrm{Cu}$ load $(\mu \mathrm{g})$ and length $(\mathrm{mm})$ of $A$. senilis , dry (a) and wet (b) seasons; Benya (circles), Ningo (half shaded) and Sakumo (dots) lagoons.
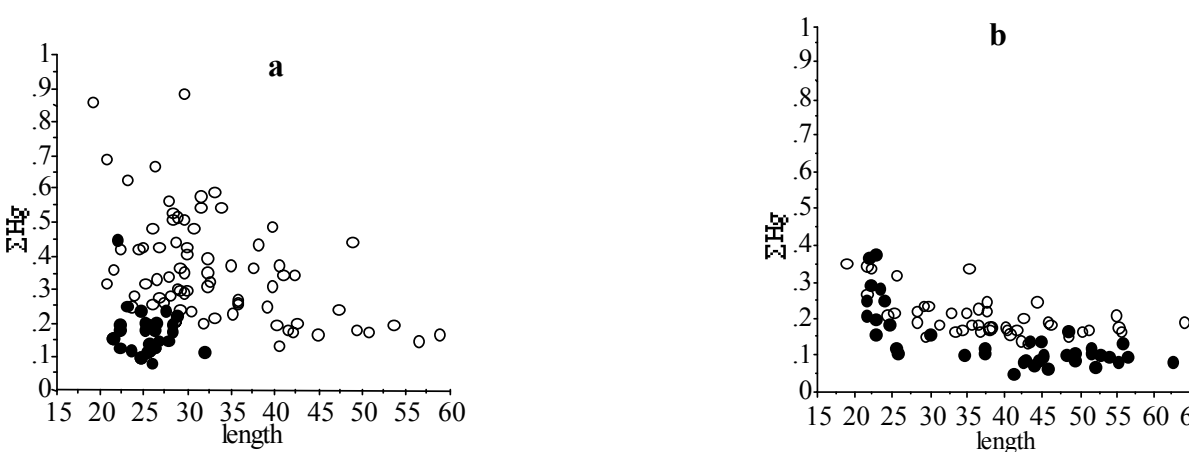

Figure 3. Relationship between $\sum \mathrm{Hg}$ concentrations $(\mu \mathrm{g} / \mathrm{g} \mathrm{dw})$ in cockles and size $(\mathrm{mm})$ : dry (a) and wet (b) seasons; Benya (circles), Ningo (half shaded) and Sakumo (dots) lagoons.

\section{RESULTS}

Median concentrations and body burden for both seasons are shown in Table 3. One important factor influencing these results is size. For example, $\mathrm{Cu}$ concentration in the dry season (cockles) decreases with size as a "growth dilution" effect but stable in the wet season (Figures $1 \mathrm{a}$ and $\mathrm{b}$ ). In this case regional differences in $\mathrm{Cu}$ could be entirely due to size effect. Likewise, the seasonal difference in $\mathrm{Cd}$ and $\mathrm{Hg}$ dry season 
Table 3. Seasonal and locational variation in concentration ( $\mu \mathrm{g} / \mathrm{g} \mathrm{dw}$ ), load (burden, $\mu \mathrm{g}$ ) of total $\mathrm{Cu}, \mathrm{Zn}, \mathrm{Fe} \mathrm{Cd}, \mathrm{Hg}$, Mn and size $(\mathrm{mm})$ in the bivalves studied: median values; Benya and Ningo are open lagoons and Sakumo a closed lagoon $n=$ number of samples.

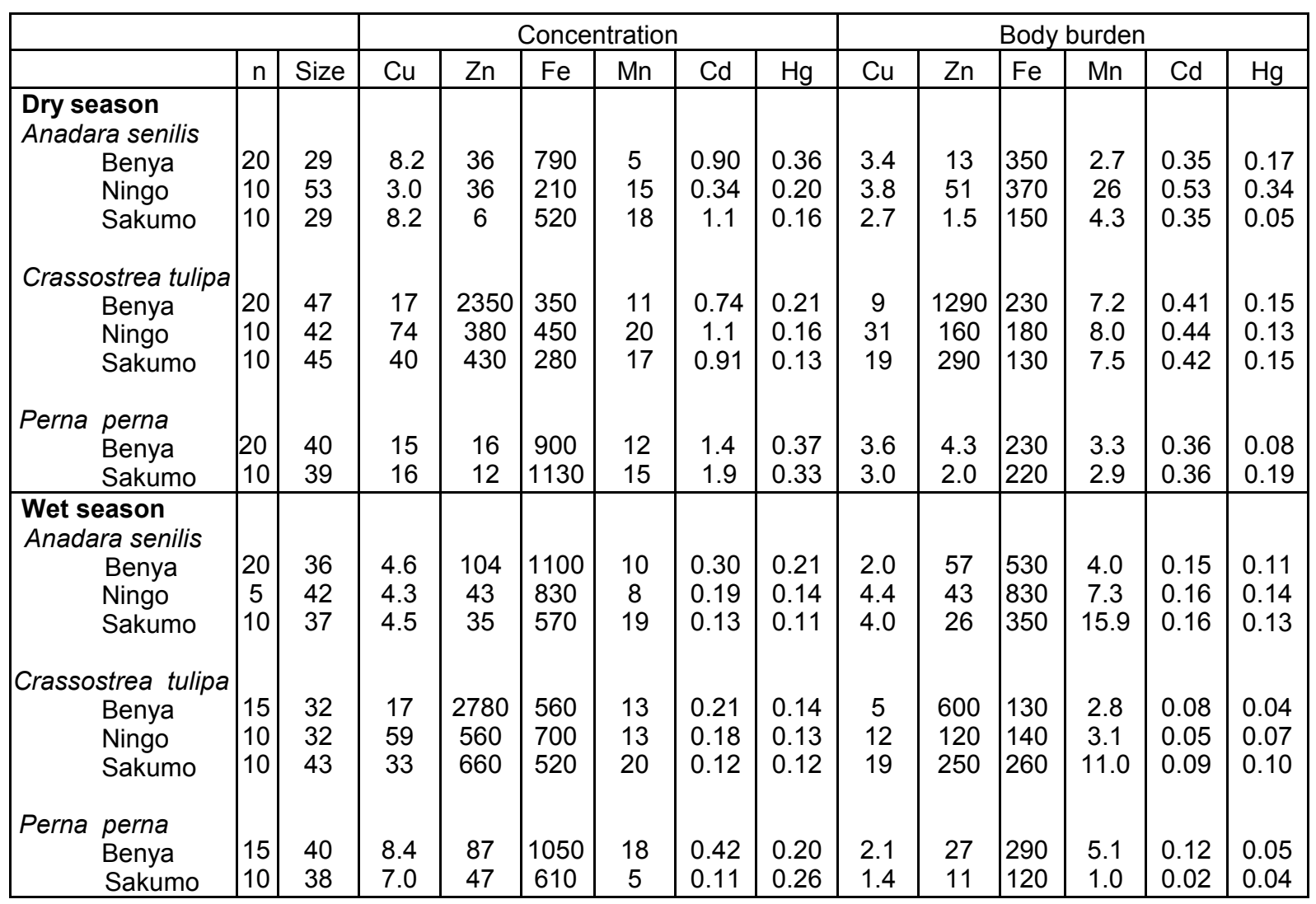

Table 4. Slope coefficient (b), intercept (a) and proportion of variation explained $\left(r^{2}\right)$ of the metal burden and the size of bivalves studied (both seasons and all stations pooled).

\begin{tabular}{|l|c|c|c|c|c|c|c|c|c|}
\hline Metal & \multicolumn{3}{|c|}{ Cockles } & \multicolumn{3}{c|}{ Oysters } & \multicolumn{3}{c|}{ Mussels } \\
\hline & $\mathrm{a}$ & $\mathrm{b}$ & $\mathrm{r}^{2}$ & $\mathrm{a}$ & $\mathrm{b}$ & $\mathrm{r}^{2}$ & $\mathrm{a}$ & $\mathrm{b}$ & $\mathrm{r}^{2}$ \\
\hline Copper & -1.01 & 0.99 & 0.39 & -0.95 & 1.26 & 0.19 & -4.2 & 2.89 & 0.18 \\
Zinc & -3.88 & 3.37 & 0.60 & 0.77 & 1.16 & 0.10 & -1.99 & 1.74 & 0.02 \\
Iron & 0.30 & 1.48 & 0.37 & 0.80 & 0.9 & 0.20 & -1.05 & 2.12 & 0.17 \\
Cadmium & -4.83 & 2.57 & 0.44 & -3.61 & 1.46 & 0.29 & -6.31 & 3.28 & 0.06 \\
Manganese & -3.4 & 2.73 & 0.50 & -1.34 & 1.31 & 0.31 & -5.82 & 3.93 & 0.28 \\
Mercury & -3.36 & 1.62 & 0.48 & -3.18 & 1.34 & 0.05 & -3.74 & 1.64 & 0.09 \\
\hline
\end{tabular}

concentrations were also apparently higher than those in the wet season. A closer look at the total body burden data with respect to these metals seasonal differences could be detected. Comparing Benya and Sakumo wet season body burden (with larger cockle sizes; $37 \mathrm{~mm}$ ) to dry season $(29 \mathrm{~mm})$ suggest a lower metal availability (Cd) at the stations during the wet season. Thus the above seasonal differences in $\mathrm{Cd}$ and $\mathrm{Hg}$ concentrations are real.

Both body burden and concentrations in these metals showed no geographical difference during the seasons and any seeming difference was due to size/age. While $\mathrm{Zn}, \mathrm{Fe}$ and $\mathrm{Mn}$ dry season concentrations were lower than wet season. Again considering the body burden the 
Table 5. Slope coefficient (b), intercept (a) and proportion of variation explained $\left(r^{2}\right)$ of the metal load and the size of cockles; dry season (see legend to table 3 ).

\begin{tabular}{|l|c|c|c|c|c|c|c|c|c|}
\hline Metal & \multicolumn{4}{|c|}{ Benya } & \multicolumn{4}{c|}{ Ningo } & \multicolumn{3}{c|}{ Sakumo } \\
\hline & $\mathrm{a}$ & $\mathrm{b}$ & $\mathrm{r}^{2}$ & $\mathrm{a}$ & $\mathrm{b}$ & $\mathrm{r}^{2}$ & $\mathrm{a}$ & $\mathrm{b}$ & $\mathrm{r}^{2}$ \\
\hline Copper & -1.49 & 1.37 & 0.82 & -1.12 & 1.0 & 0.25 & -0.4 & .57 & 0.39 \\
Zinc & -3.3 & 3.01 & 0.55 & -1.75 & 2.05 & 0.88 & -4.94 & 3.63 & 0.79 \\
Iron & -.34 & 1.95 & 0.90 & -0.53 & 1.79 & 0.56 & -0.72 & 2.04 & 0.77 \\
Cadmium & -5.54 & 3.34 & 0.76 & -3.99 & 2.17 & 0.85 & -1.05 & 0.39 & 0.25 \\
Manganese & -2.94 & 2.24 & 0.43 & -1.21 & 1.48 & 0.14 & 0.41 & 0.15 & 0.01 \\
Mercury & 3.48 & 1.83 & 0.46 & 1.47 & 0.62 & 0.29 & 3.66 & 1.7 & 0.19 \\
\hline
\end{tabular}

$\mathrm{Y}=\mathrm{aW} \mathrm{W}^{\mathrm{b}}$, where $\mathrm{Y}$ is the load, $\mathrm{W}$ the size, a the intercept and $\mathrm{b}$ the slope co-efficient (Boyden, 1974).

influence of size is obvious from the table; Mn did not show any difference both in location and season. Any detected differences in concentration and burden were apparent. On the other hand seasonal differences could be found in $\mathrm{Fe}$ and $\mathrm{Zn}$ concentrations. For example, Ningo dry season burden (with higher biomass) was lower than wet season, an indication of a higher contamination of these metals in the wet season. Geographical differences could be detected in other species, such as higher $\mathrm{Zn}$ concentration in oysters from Benya during both seasons. Seasonal variations on the other hand, could be detected mainly due to hydrological differences like the effect of rain or differences between open and closed lagoons. Elevated levels of $\mathrm{Zn}$ in oysters $(270-3540 \mu \mathrm{g} / \mathrm{g} \mathrm{dw})$, Fe in cockles (150- $2050 \mu \mathrm{g} / \mathrm{g} \mathrm{dw}$ ) and in mussels $(510-1880 \mu \mathrm{g} / \mathrm{g} \mathrm{dw}$ ) reflect the inherent variability of metals in bivalves dependence on the particular species-metal pair considered, and also on the degree of contamination involved (Boyden and Phillips, 1981).

\section{DISCUSSION}

In order to avoid the problem of cases where it is difficult to assess whether observed differences in tissue level/burden between these bivalves reflect real differences in environmental heavy metal constitution, or are merely due to variations in body size, plots of $\mu \mathrm{g}$ metal per individual (total burden versus size) was carried out. Generally, the total metal burden is related to body weight/size by the metabolic power function: $Y=a W^{b}$, where $Y$ is the burden, $W$ the dry weight, a the intercept and $b$ the slope co-efficient (Boyden, 1974). Coefficients $\geq 2$ of the body weight as shown by $\mathrm{Cd}, \mathrm{Zn}$ and $\mathrm{Mn}$ in cockles and $\mathrm{Cu}, \mathrm{Fe}, \mathrm{Cd}$ and $\mathrm{Mn}$ in mussels (Table 3) can best be explained as being due to removal of this elements from body circulation and accumulation within specific tissues, possibly as a result of some exceptional affinity. In the case of the oysters (Table 4) all the relationships were approximately equal to one $(b=1)$, implying that element concentration was independent of size. The absolute amount of the metal is not dictated by the amount of such binding compound/storage mechanisms in the tissues.

The tendency to decrease the metal concentrations with an increase in body weight is not significant in all cases. However, for the essential metals $\mathrm{Cu}$ and $\mathrm{Fe}$ (in cockles and oysters) the size of the animal could be mainly responsible for the metal concentration variability. The slope value of about 2 in cockle population examined (Table 5) may well be due to the unusually elevated environmental $\mathrm{Fe}$ concentration in the lagoons. An increase in metal burden with size/weight of the individuals is expected and it is indeed noted for all metals, except for $\mathrm{Zn}$ and $\mathrm{Cd}$ in mussels. Information about the factors responsible for the observed metal burden-size can be obtained from the slope of the regression lines (Table 5).

The changes in metabolic rates of bivalves with length and season as well as the variation in bioavailability of metals in the surrounding environment with time might be responsible for these variations in these molluscs (Boyden, 1974; Cossa and Rondeau, 1985). Metal availability probably fluctuated with salinity in these lagoons during the seasonal cycle (Phillips, 1977; Cossa and Rondeau, 1985). This probably caused the higher metal burden and concentration in the wet season (such as for $\mathrm{Fe}$ and $\mathrm{Zn}$ ). Higher wet season levels of $\mathrm{Fe}$ and $\mathrm{Zn}$ might as well be due to 'import' as most roofing in Ghana are made of galvanized iron sheets. Lower wet season levels for $\mathrm{Cd}$ and $\mathrm{Hg}$ could be attributed to lost through spawning or washed-out of the lagoons during the rainy period. Many metals are also found in agricultural products. Those present in fertilizers include $\mathrm{Cd}, \mathrm{Cu}, \mathrm{Cr}$, $\mathrm{Ni}, \mathrm{Mn}$, Mo and $\mathrm{Zn}$. Eventually, many of these metals may accumulate in soils and become exposed to run-offs during the rainy season. Biological variables such as size, sex or changes in tissue composition and reproductive cycle as well as the season of sampling and the hydrodynamics of the lagoons have to be considered. Seasonal variations have been reported to be higher in winter/dry than in summer/wet. These seasonal variations have been related to a great extent to seasonal changes in flesh weight during development of gonadic tissues (Cossa and Rondeau, 1985; Joiris et al., 1998; Otchere et al., 2000, 2003). 


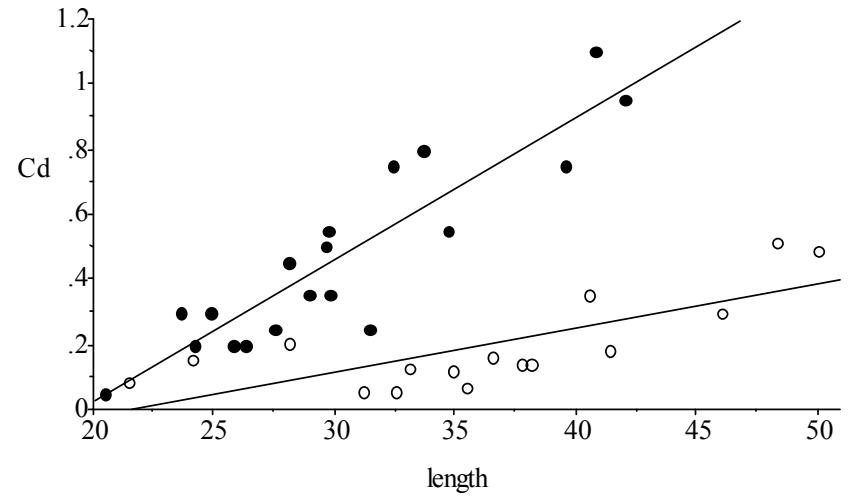

Figure 4. Relationship between $\mathrm{Cd}$ body burden $(\mu \mathrm{g})$ and size $(\mathrm{mm})$ of cockles from Benya; dry season (dots) and wet season (circles).

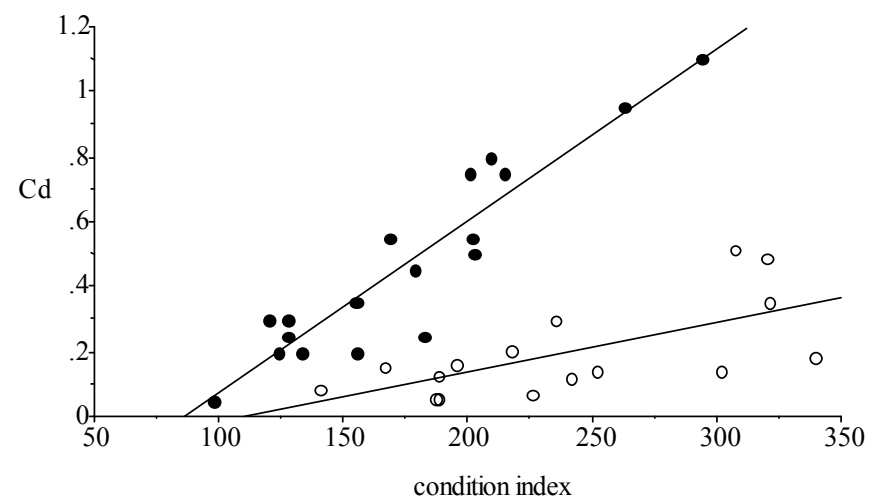

Figure 5. Relationship between total $\mathrm{Cd}$ body burden $(\mu \mathrm{g})$ and $\mathrm{Cl}$ of cockles from Benya; dry season (dots) and wet season (circles).

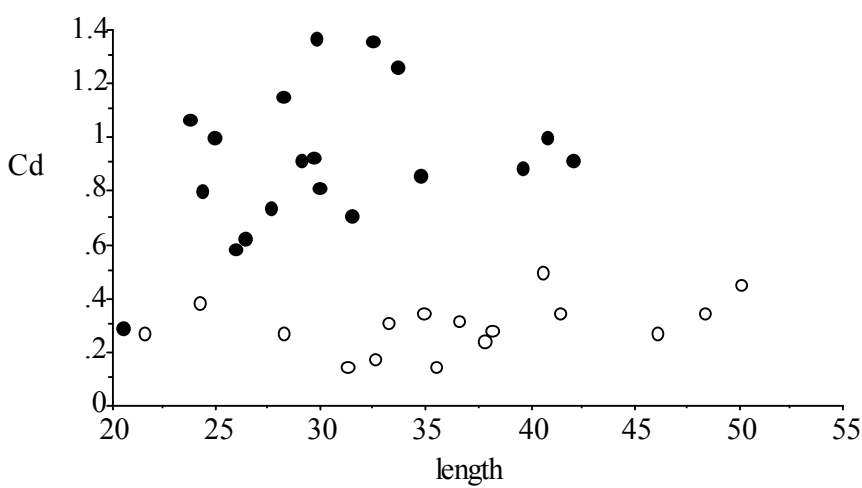

Figure 6. Relationship between Cd concentration $(\mu \mathrm{g} / \mathrm{g} d w)$ and size $(\mathrm{mm})$ of cockles from Benya; dry season (dots) and wet season (circles).

Metabolic changes of the mollusc with age and season, storage mechanisms as well as temporal variations in metal bioavailability in the surrounding environment might be the reasons to explain these burden-size relationships in the lagoons (Tables 4 and 5). In molluscs, absolute tissue levels are related or determined by environmental levels. In cases where the body burden is directly related to body weight, as has been found for a variety of elements in several species (Boyden, 1974), a function of body weight such as binding of specific compounds within the tissue may play some role in determining the total burden. The amount of metal, however, may not depend on the amount of such binding compounds within the tissues but on the amount of metal available in that environment. Thus both biotic and abiotic factors probably constantly change their relative importance in these bivalves and it is unlikely that a steady state could ever be reached. Finally seasonal and regional variations observed in this study were likely to be due to these factors mentioned above. Results on metal contamination in bivalves should therefore not to be used directly as reflecting environmental contamination; they should first be normalized for these physical and environmental factors before any spatial and/or temporal comparison is made.

\section{Excretion and accumulation model}

Metal penetration in bivalves may take place in several ways: diffusion of ions or complexes, mediated transport and/or endocytosis of particulate metal and pinocytosis of organo-metallic aggregates. Uptake may take place at the gill or digestive gland or on the surface of the mantle, and their relative importance is a function of the speciation of the metal in the environment. Differences in metal load (body burden) and flesh weight of the bivalves have been the main influences on the level of contamination in this study. The origin and range of variations in concentrations of these pollutants can be described through the Figures 4 to 7.

Considering $\mathrm{Cd}$ concentration in cockles in the wet and dry seasons, the slope of the $\mathrm{Cd} /$ size relationship results from a combination of several factors which act separately or simultaneously. The figures reflect the competition between the opposite effect of age and growth on the accumulation of $\mathrm{Cd}$. The metal accumulates with age whereas the weight gain of the individual has the effect of reducing the metal concentration. The relationship observed underlying the linear relation could effectively correspond in a given range of soft tissue weights to the presence of individuals of the same age class whose soft tissue weight differs considerably. In this way, while the $\mathrm{Cd}$ burden would increase with age (Figure 4), concentration would diminish with the weight/size (Figure 6) within each age class if growth is more rapid than the accumulation rate.

To the inverse effect of age and soft tissue weight is added the effect of change in the bioavailability of $\mathrm{Cd}$ in the environment. To demonstrate these mechanisms clearly the phenomenon in the light of situations encountered in cockles will be restated: that in bioaccumulation in bivalves, the uptake of the metal is higher in the smaller individual than in the larger ones generally resulting in "growth dilution" effect. The result is 

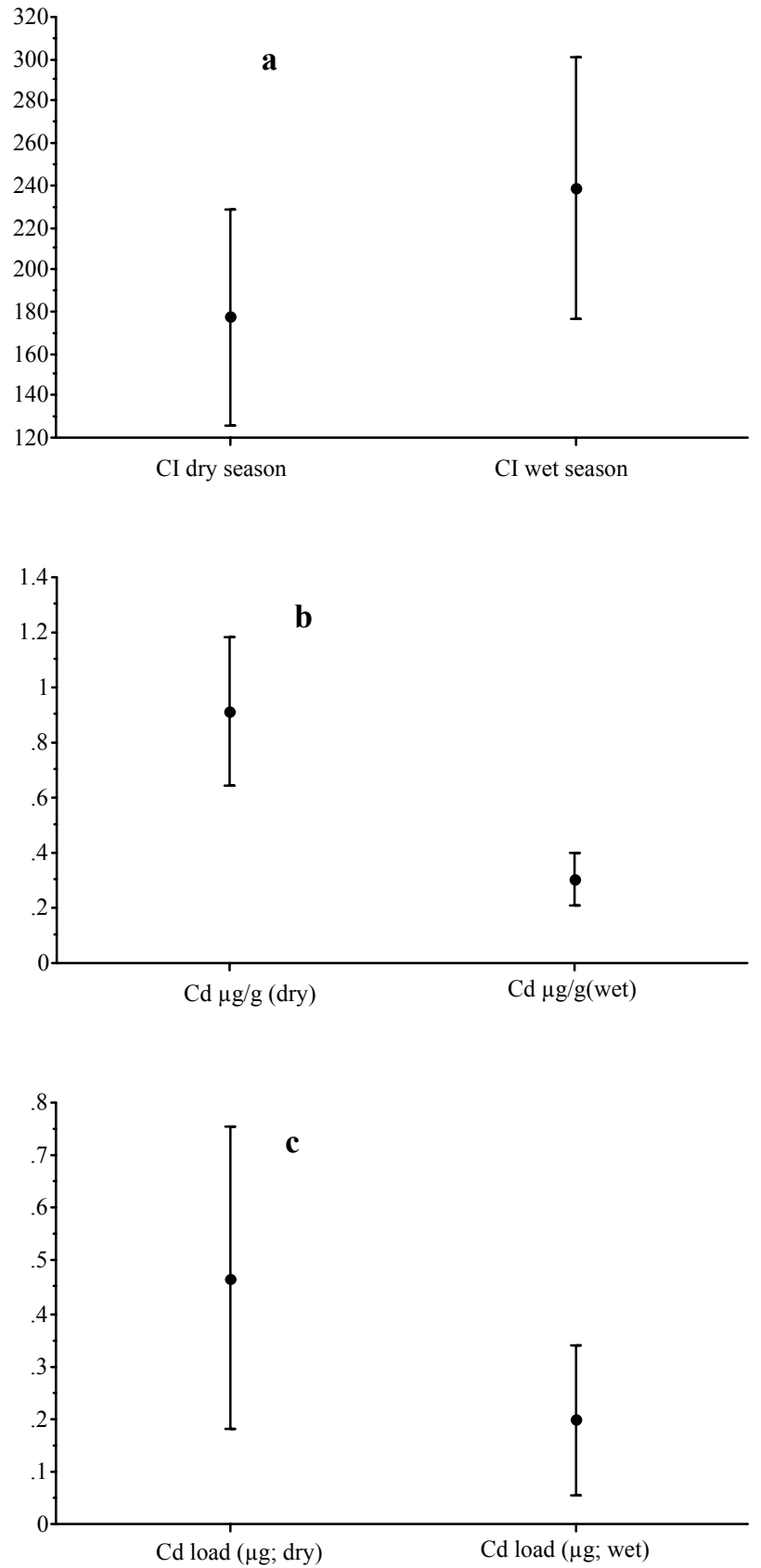

Figure 7. One bar standard error from the mean for $\mathrm{Cl}(\mathrm{a})$, body burden (b) and concentrations (c) in cockles from Benya during the dry and wet seasons.

a negative slope for metal/size concentration relationships in the case of $\mathrm{Hg}$ (Figure 3) but not in $\mathrm{Cd}$ as in Figure 6 (for the non-essential metals), which was only due to seasonal effect. Higher metabolism in juvenile individuals can cause a reduction in metal concentrations in soft tissue, because the tissue grows more quickly than the metal can be absorbed. This mechanism can explain seasonal variations recorded in $\mathrm{Cd}$ concentrations. In Figure 7 , condition index $(\mathrm{Cl})$ in the wet season was higher than the index in the dry season while load was higher in the dry season than in the wet season expressing their opposite effect on concentration and explaining the seasonal variations observed in $\mathrm{Cd}$ concentration in cockles.

Applying the same principle as in $\mathrm{Cd}$ to $\mathrm{Zn}$ and $\mathrm{Cu}$ would explain the variations observed. $\mathrm{Cl}$ was higher in the wet season than in the dry season for both metals. For example, while load (body burden) was higher in dry season for $\mathrm{Cu}$ expressing the opposite effect on concentration to explain the temporal difference observed. Comparative differences between wet and dry seasons for $\mathrm{Cu}$ and $\mathrm{Zn}$ were about 1.3-fold and 3-fold increase respectively. The difference was not significant in $\mathrm{Cu}$ because as an essential element it is strictly regulated; contrarily $\mathrm{Zn}$ showed a significant seasonal variation due to the elevated level in the Ghana environment as a result of galvanized roofing sheet used thus $\mathrm{Zn}$ becomes more available during the rainy period than the dry season. Therefore $\mathrm{Zn}$ regulation in cockles could be described to have broken down due to elevated levels in the environment. It is clear that concentrations of all 3 metals were mainly determined by cockle condition and seasonal fluctuations in metal concentration, which in turn depended to a large extent on the magnitude and direction of temporal alteration in the dry weight of whole soft tissue of the cockles.

Fowler and Oregioni (1976), Phillips (1976) and Boyden and Phillips (1981) studying Mytilus galloprovincialis, $M$. edulis and Crassostrea gigas respectively, concluded that temporal variations in metal concentrations were mainly caused by changes in soft tissue weights of the bivalves according to the sexual cycle. Thus alterations in the concentrations of metals reciprocated those of the whole soft tissue weights. Investigations of element seasonality in bivalves molluscs are important in terms of their implications for the use of these organisms as biological indicators of metal abundance. The present study suggest that element concentrations may commonly vary in Anadara senilis by a factor of 2 or more during the annual cycle. Clearly, such variation is a potential disruptive factor in the use of $A$. senilis to monitor metal abundance at different locations and seasons. The simultaneous sampling of cockles at all sites in such an indicator survey might be considered sufficient to overcome this source of variations, but even in this case there can be no guarantee that cockles from each locations are of similar condition. The best method for diminishing the effects of seasonality is therefore to time sampling programs to occur during a period of relatively little change in element concentrations. In addition, the effect of season could be eliminated by the removal of gonads prior to analysis.

\section{Conclusion}

Concluding, the wet season maxima in $\mathrm{Zn}, \mathrm{Fe}$ and $\mathrm{Mn}$ observed should reflect a higher metal availability during this season (through 'import'). The four essential metals 
which were studied, were present in similar respective concentrations to those found for other bivalves elsewhere and exhibited similar seasonal pattern in terms of their concentrations although of different magnitudes (Boyden and Phillips, 1981; Reinfelder et al., 1997; Joiris and Azokwu, 1999). There was no influence of season and location on $\mathrm{Mn}$ and $\mathrm{Cu}$ concentrations, but location played an important role in $\mathrm{Fe}$ and $\mathrm{Zn}$ concentrations while season exhibited a moderate influence. Temporal variations in metal concentrations were mainly caused by changes in soft tissue weights of the bivalves according to the sexual cycle. Thus alterations in the concentrations of metals reciprocated those of the whole soft tissue weights hence its respective effect on excretion and accumulations.

\section{REFERENCES}

Boyden CR (1974). Trace element content and body size in molluscs. Nature 251: 311-314.

Boyden CR (1977). Effect of size upon metal content of shellfish. J. Mar. Biol. Assoc. 57: 675-714.

Boyden CR, Phillips DJH (1981). Seasonal variation and inherent variability of trace elements in oysters and their implications for indicator studies. Mar. Ecol. Prog. Ser. 5: 29-40.

Cossa D, Rondeau JG (1985). Seasonal, geographical and size induced variability in mercury content of Mytilus edulis in an estuarine environment: a re-assessment of mercury pollution level in the Estuary and gulf of St. Lawreence. Mar. Biol. 88: 43-49.

Fowler SW, Oregioni B (1976). Trace metals in mussels from the N.W. Mediterranean. Mar. Pollut. Bull. 7: 26-29.
Joiris CR, Azokwu MI, Otchere FA, Ali IB (1998). Mercury in the bivalve Anadara (Senilia) senilis from Ghana and Nigeria. Sci. Total Environ. 224: 181-188.

Joiris CR, Azokwu MI (1999). Heavy metals in the bivalve Anadara (Senilia) senilis from Nigeria. Mar. Pollut. Bull. 40: 457-460.

Joiris CR, Holsbeek L, Otchere FA (2000). Mercury in the bivalves Crassostrea tulipa and Perna perna from Ghana. Mar. Pollut. Bull. 38: 618-622.

Otchere FA, Joiris C, Holsbeek L (2003). Mercury in the bivalves Anadara (Senilis) senilis, Perna perna and Crassostrea tulipa from Ghana. Sci. Total Environ. 304:369-375.

Otchere FA, Joiris C, Holsbeek L, Ali IB, Vanderpuye CJ (2000). Heavy metals concentration and burden in the bivalves Anadara (Senilia) senilis, Perna perna and Crassostrea tulipa from Ghana; In: 11th Annual International Conference on Heavy Metals in the Environment (J. Nriagu, ed.), Contrbution number 10161. University of Michigan, School of Public Health, Ann Arbor, MI (CD-ROM).

Phillips DJH (1976). The common mussel Mytilus edilus as an indicator of pollution by zinc, cadmium, lead and copper. I. Effect of environmental variations on uptake of metals. Mar. Biol. 38: 56-69.

Phillips DJH (1977). Effects of salinity on the net uptake of Zinc by the common mussel Mytilus edulis. Mar. Biol. 41: 79-88.

Phillips DJH (1980). Quantitative Aquatic Biological Indicators: Their use to monitor trace metal and organochlorine pollution. Lond. Appl. Sci. Ltd. U.K.

Phillips DJH (1990). In: Furness, R.W. and Rainbow, P.S. (eds) Heavy metals in the marine environment. CRC Press, Florida: pp. 81-99.

Reinfelder JR, Wang W-X, Luoma SN, Fisher NS (1997). Assimilation efficiencies and turnover rate of trace elements in marine bivalves: a comparison of oysters, clams and mussels. Mar. Biol. 129: 443-452.

UNEP/FAO/IAEA (1982). Determination of total Cadmium, Zinc, Lead and Copper in selected marine organisms by Atomic Absorption Spectrometry. Reference methods for marine pollution studies No. 11. United Nations Environmental Programme.

Yankson K (1982). Gonad maturation and sexuality in the West African bloody cookle, Anadara senilis (L). J. Molluscan Stud. 48: 294-301. 